\title{
Effectiveness of Project Based Learning on Empowerment Critical Thinking Skill toward Pre-service Teacher on Primary Teacher Education Program
}

\author{
Kartika Chrysti S ${ }^{1}$, Sajidan ${ }^{1}$, Sentot Budi $\mathrm{R}^{2}$, Zuhdan Kun $\mathrm{P}^{3}$ \\ ${ }^{1}$ Faculty of Teacher Training and Education, Universitas Sebelas Maret Indonesia, Ir. Sutami No.36A \\ Street, Jebres, Kota Surakarta, Jawa Tengah 57126 \\ ${ }^{2}$ Faculty of Science, Universitas Sebelas Maret Indonesia, Ir. Sutami No.36A Street, Jebres, Kota \\ Surakarta, Jawa Tengah 57126 \\ ${ }^{3}$ Faculty of Science, Yogyakarta State University Colombo No.1, Depok, Caturtunggal, Sleman, \\ Kabupaten Sleman, Daerah Istimewa Yogyakarta 55281
}

Email: kartika@staff.uns.ac.id

\begin{abstract}
The aims of the research to empirically test of empowerment critical thinking skills toward preservice teacher through Project Based Learning (PjBL) in Primary Teacher Education Programs. The research was done by quasi experimental (Research Based Learning) and comparison (traditional instruction) groups. The research was conducted in the second-semester student in a primary teacher education program. The students have taken the course of basic concept science. Critical thinking was developed by the preservice teacher in the primary teacher. Quantitative data were obtained via the pre/post-test, treatment-control groups test model. Data were analyzed through descriptive statistics and independent sample ttests. The result shows critical thinking effectively applied on PjBL group. Implications future of the research uses more representative samples to avoid bias.
\end{abstract}

Key words: Project Based Learning; Critical Thinking; pre service teacher

\section{INTRODUCTION}

Higher order thinking skills (HOTs) are prepared for young people in 21st century. HOTs were the empowerment of people especially toward the student in the primary teacher [1]. The definition of empowerment is the process of becoming stronger and more confident, especially in controlling one's life and claiming one's rights [2]. High order thinking consists of critical thinking, creative thinking and problem solving; however in this study is emphasized critical thinking. The critical thinking paradigm includes definitions that refer to logical thinking that is focused on deciding what to believe or 'reasoning thinking'. Critical thinking was categorized at sixth section include interpretation, analysis, inference, evaluation, explanation, and self-regulation [3]. 
The original definition or critical thinking was conveyed by Dewey. Critical thinking is ideas or ideas that arise consciously from oneself. In other words, critical thinking is a reflective idea as an effort to participate in providing logical and analytical ideas [4]. Students who are trained to think critically have the competence to provide feedback from existing problems. Teachers' engagement student in primary teacher education to habituate critical thinking. The purpose of teaching is then to guides students to be able how to make right decisions and judgment [5].

Project-based learning stages are almost identical to an inquiry, but it is more complex and detailed to examine the object of the problem [6;7]. PjBL suggested involving of students with research activities that enable them to recognize the variation and complexity of constructing knowledge in different disciplines. PBL involves students to be active and independent in addressing any issues. Students are invited to think critically, creatively, analytically and logically as problem solvers. They should be improved innovative abilities, reasoning thinking and problem-solving. National Science Foundation (NSF, USA) determinant that "The twentieth century saw the university change from a site in which teaching and research stood in a reasonably comfortable relationship with each other $r$ to one in which they became mutually antagonistic.” [7]

\section{LITERATURE REVIEW}

One of the global challenges for universities is to provide knowledge and education for the younger generation. In the international framework world especially learning in Europe there is a tendency of research activities to increase the ability to explore new ideas [8]. The research objectives are reviewed from various aspects of strengthening the needs of stakeholders, students, teachers, practitioners and professionals. The constructivism model encourages active participation in learning to build knowledge. Assignment to students as one of the activities and skills of students in learning. In the assignment students are trained to build new knowledge in a structured manner. This is in accordance with the concept of modern constructivism theory which states knowledge-based direct experience in everyday life [9]. Experience can take place during class activities or in connection with daily life. Development of experience related to the concept and process of science. $\mathrm{PjBl}$ involves students doing deeper inquiry, critical thinking and problem-solving. This activity is closely related to 21st-century skills including 4C consisting of critical, creative, communication and collaboration [14].

Research with the inquiry is important to improve the quality of teaching and learning. Research and results are useful in all areas. Therefore, as an educator able to show the stages of research and the results used for the development of learning. Effective research in teaching and learning process if teachers apply to research or results to improve the quality of learning [10].

Researchers and teachers develop instruction-based or project-based learning for students. Students are emphasized to experiment with various variations on independent variables and dependent variables. Teachers/lecturers use an inquiry learning model where students are stressed to try and find themselves based on the scientific methods [11] states that teachers/lecturers can use his teaching style 
combined with the results of research in learning. Teachers are not enough to simply transfer knowledge to students but engage them in building new knowledge. Students are not just knowledge users who are memorized but invite them to think constructivism form a new paradigm. Teachers should be able to relate the concept of science in everyday life [12].

According to Hsu, there is an emphasis on knowledge science on project-based learning on teachers and students [13]. Teachers emphasize that on project-based learning materials, while the students on the learning process inquiry during class or laboratory activities. Project-based learning (PjBL) is a learning system using authentic learning, problem solving, cooperative learning, hand on and minds on, discovery and inquiry based on constructivism philosophy [12]. Students are trained to be independent to build new knowledge. With PjBL giving students the advantage to test the hypothesis, find data, analyze and draw conclusions. Therefore, PBL familiarize students not only understand the concept of science but can relate the concept in practice in terms of everyday events [17].

The PjBL is reviewed from a multidisciplinary range of emphasizing students' engagement and direct participation. Students are trained to deductive and inductive thinking during the learning process. In the experimental and investigative activities trained to connect the independent variables and dependent variables [5;17]. PjBL as well as inquiry study related to research involves students to behave like scientists forming new knowledge [16].

$\mathrm{PjBL}$ is equivalent to inquiry emphasizes students to think critically, can reflect, examine events in depth and build knowledge. In other words students are invited to participate to have a deeper understanding of a concept of science. Students are involved in identifying and formulating problems in different perspectives. Students think critically and meta-cognitively [16].

Facione [3] argues that critical thinking is an individual process for analyzing an event logically, making sense and then finding a solution. The critical thinking indicator consists of interpretation, explanation, analysis, inference, evaluation, and self-regulation.

Critical thinking is the competence of each individual by integrating, scientific methods and pragmatic thinking. Individuals who have the critical thinking to see events in a rational, analytical and problem solving like scientists [18]. The ability to think critically followed by creative thinking is to bring up new ideas that are original [13].

\section{Research Questions}

1. What is Project Based Learning more effectively applied in science learning than conventional models?

2. How did Project-based learning improving critical thinking skills preservice teacher at primary education program? 


\section{METHOD}

\section{Procedure}

For this research is experimental study, at the beginning of the lesson were given a set of pre-test to the control and treatment groups. The questions for a set of pretest and post-test are of equal quality for both groups at the time of learning is conducted.

This study is a quasi-experiment with groups and control groups. To test the variables by using pre-test and post-test. The researchers selected the control group and the group treated randomly. Furthermore, the control group applied the conventional model but treatment group by playing $\mathrm{PjBL}$ during the learning process. To see the effectiveness of PjBL models compare results before and after learning.

\section{Participants}

Thirty-six student (6 male and 30 female) were selected for the control group (conventional model) and another 38 (5 male and 33 female) students for the treatment group $(\mathrm{PjBL})$. Treatment group uses $\mathrm{PjBL}$ model on learning process.

\section{Data Collection}

The beginning and implementation of each type of activity. Data were also obtained from the students' Worksheet as well as the objective matter. In addition, the purpose of the use of tests in this study is to measure students' abilities and compare the results of learning science, especially in terms of critical thinking. Group treated with PjBL model and control group with the conventional model. At the end of the study were tested to measure the improvement of critical thinking in both groups. Data were analyzed by inferential static in both groups.

\section{Instrumentation}

The instrumentation consists of 35 objectives questions along with the reason critical thinking consist of analysis, explanation, interpretation, conclusion, evaluation, and self-regulation [19]. Each question consists of 5 item selection choice for answers and reasons. If the answer and reason are true so the score is given 3 points, if the answer is true but the reason is false so the score is given 2 points, the answer is false but the reason is true so the score is 2 point, if the both are false so the score is given nol.

The pre-test and post-test were conducted for both groups and data were collected for analysis using SPSS version 18.0. Then, an experiment was applied for both groups. For the treatment group used PjBL model during their science lessons for 6 weeks. However, for the control group, their science lesson was conducted without PjBL model but used conventional model. After the learning is complete then the both groups have been conducted post-test for data collecting.

\section{Data Analysis}

Data analysis used in this research is descriptive analysis and an inferential statistic that is the percentage, average, and standard deviation. To know the effectiveness of PjBL model in science learning with a pre-post test, performance 
assessment, and product. Further analysis with $t$ test if greater than $t$ arithmetic is different significance. The t-test is used to see the difference of treatment in the group with PjBL and control learning. Normality test of both groups was done with Kolmogorov-Smirnov test. To determine the difference between variance and mean, the Lavene sample and independent T-tests at $\alpha=0.05$ are used.

\section{RESULT}

The results showed experimental group with a treatment of $\mathrm{PjBL}$ model and control group analyzed inferential statistic Table 1. Both experimental and control group compared pre-test and post-test. The mean values of control group pretest (64.5) and treatment group (66.70). Similarly for control group test post $(76,20)$ and treatment group $(70,0)$. From both groups showed that the group with the application of PBL model is higher than the conventional model group.

TABLE I. THE RESULT OF T-TEST FOR PRE AND POST TEST

\begin{tabular}{|lllllllll|}
\hline \multirow{2}{*}{ Group } & \multirow{2}{*}{ N } & \multirow{2}{*}{ Mean } & \multicolumn{3}{c}{ Std Dev } & \multicolumn{3}{c|}{ Std error mean } \\
& & & Pre & Post & Pre & Post & Pre & Post \\
\hline \multirow{2}{*}{ Value } & PjBL & 36 & 66,77 & 76,20 & 13,80 & 7,82 & 2,30 & 1,30 \\
& Control & 35 & 64,50 & 70,00 & 12,03 & 9,96 & 2,03 & 1,68 \\
\hline
\end{tabular}

Further tests were used to see the differences between the two treatment and control groups on pre-test and post-test. A number of samples for model PjBL N: 36 and control N: 35.

TABLE II: THE RESULTS OF T-TEST FOR PRE TESTS

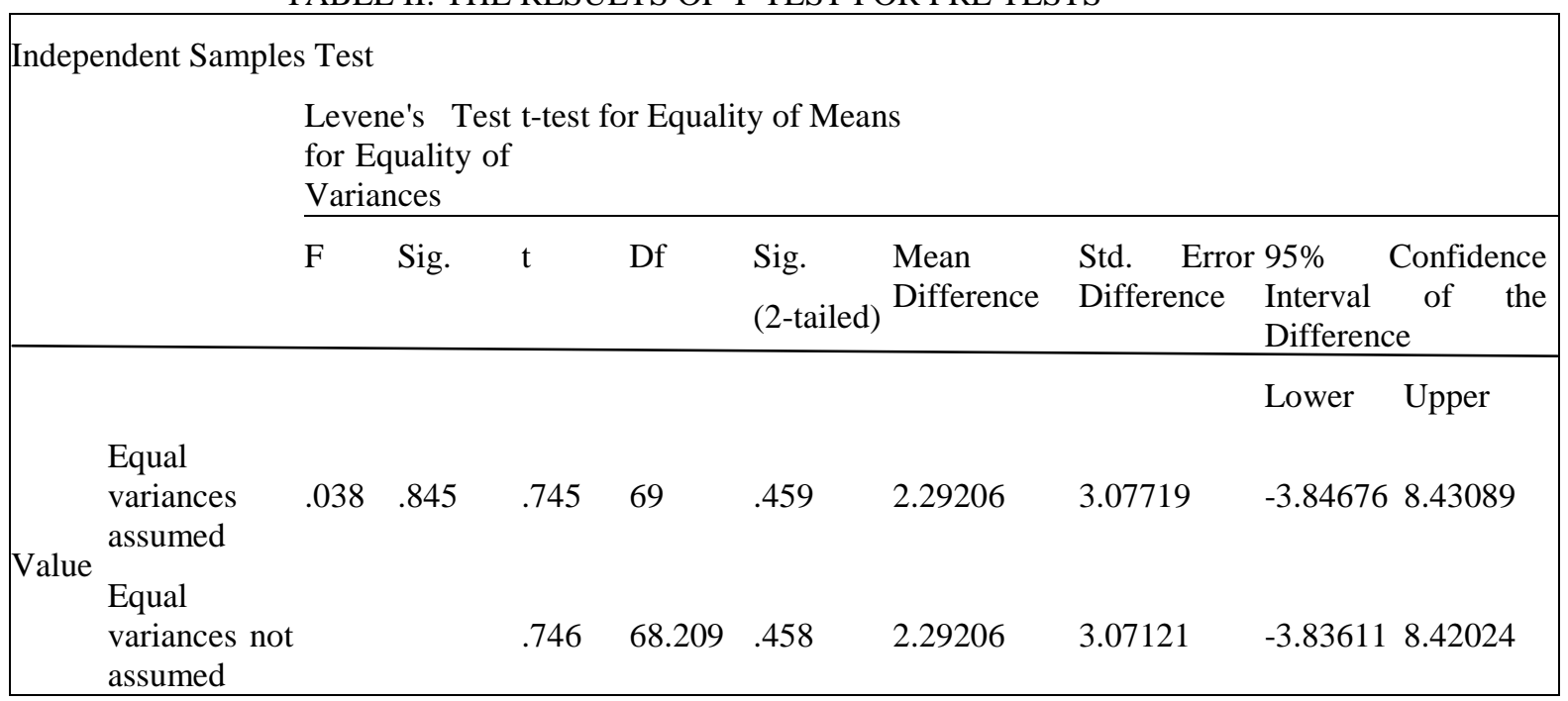

Based on Table 2. Independent Samples Test there is a difference in the treatment group and the control group. Levene's Test Test for equality of variances assumed with F: 0.038 and t: 0.745 . $(\mathrm{P}=0.95)$. Levene's test is used to prove that data is normally distributed. Therefore control and experiment groups are obviously not significant. 
TABLE 3: THE RESULTS OF T-TEST FOR POST TESTS

\begin{tabular}{|c|c|c|c|c|c|c|c|c|c|c|}
\hline \multicolumn{11}{|c|}{ Independent Samples Test } \\
\hline & & \multicolumn{9}{|c|}{$\begin{array}{l}\text { Levene's Test t-test for Equality of Means } \\
\text { for Equality of } \\
\text { Variances }\end{array}$} \\
\hline & & $\mathrm{F}$ & Sig. & $\mathrm{T}$ & Df & $\begin{array}{l}\text { Sig. } \\
\text { (2-tailed) }\end{array}$ & $\begin{array}{l}\text { Mean } \\
\text { Difference }\end{array}$ & $\begin{array}{l}\text { Std. Error } \\
\text { Difference }\end{array}$ & $\begin{array}{l}95 \% \\
\text { Interval } \\
\text { Differenc }\end{array}$ & $\begin{array}{l}\text { Confidence } \\
\text { of the } \\
\text { ce }\end{array}$ \\
\hline & & & & & & & & & Lower & Upper \\
\hline \multirow[b]{2}{*}{ Value } & $\begin{array}{l}\text { Equal } \\
\text { variances } \\
\text { assumed }\end{array}$ & 1.458 & .231 & 2.917 & 69 & .005 & 6.19444 & 2.12389 & 1.95740 & 10.43149 \\
\hline & $\begin{array}{l}\text { Equal } \\
\text { variances } \\
\text { not } \\
\text { assumed }\end{array}$ & & & 2.907 & 64.485 & .005 & 6.19444 & 2.13109 & 1.93772 & 10.45117 \\
\hline
\end{tabular}

Based on the result of $t$ test in table 3 shows that there is a significant difference there are group treatment and control group. The Levene's test to show there are significant differences between experiment group $\mathrm{PjBL}$ and control. The value $\mathrm{F}$ $(1,458)$ and $\mathrm{T}(2,917) \mathrm{P}>0,05$ so that can be concluded that Hypothesis (Ho) be accepted or the variance is equal. Therefore group experiment $\mathrm{PjBL}$ is the significant difference with a control group.

\section{DISCUSSION}

Empowering critical thinking in prospective students is better applied to the class with the application of PjBL model. Science learning takes temperature-conversion materials in living and integrated thematic environments. The tasks of lecturers based on the project have a positive impact on thinking ability. The subject consists of 1) measurement of human body temperature and environment thermometer, 2) conversion of temperature, convection, and radiation. The material is applied to the treatment class with PjBL model and control class with the conventional model. Students form small groups in the PjBL model for project completion. Activity is meant for them to communicate, mutually to solve the problem. Students are trained critical thinking and analysis to complete a project.

Students search for literature or journals related to get information. The results of research from scientific journals are read and studied as the basis of getting initial knowledge, especially the concept of temperature changes. Next, they do an investigation of the project. Investigations were conducted in groups to measure body temperature with 10 human samples of different ages, sexes, and activities using a thermometer as an accurate measuring instrument. Necessary skills in measuring and reading thermometer scale. Students obtain data which are then 
analyzed, interpreted, explained and summarized. Students write a research report on the results of the investigation to be presented.

Based on the application of the field that the class that applies the model PjBL more effective to understand the concepts of science. Students are trained to make the product at the end of the lesson and make a research report presented. Critical thinking skills are empowered to formulate problems, hypothesize, interpret research data. Students are empowered to explain the data relationships gained during working on projects with the concepts of science that are linked in everyday life and make conclusions based on the projects that have been done. However, it is difficult for students to evaluate and advise on the project. This is due to activity evaluation and self-regulation related to metacognitive ability that is about self-awareness for better. These metacognitive skills are often less emphasized during learning [15].

Students are trained to analyze, explain and infer normal and abnormal temperatures in humans. Critical thinking skills and group work are empowered in PjBL learning. Aspects of critical thinking skills that arise in learning using this PjBL model is the ability to analyze, interpret, explain and conclude. Evaluation skills and self-regulation have not yet emerged; this is because they have difficulty providing self-assessment at the time of learning that is related to metacognition ability. Students need to be trained and empowered to skillfully think critically, creatively so as to overcome problems related to the concept of science in everyday life.

PjBL stages students are involved and empowered to think critically, logically, analytically to find solutions to problems. The concept of science is associated with data obtained during the investigation for discussion. Thinking skills measured by rational thinking skills include analytical skills, interpretation, explanation, evaluation, conclusions, and self-regulation [3].

Student-centered PjBL activities train metacognitive skills especially critical thinking, able to predict, explain causal relationships and be able to argue. Students are also trained to have an honest, objective and open-minded attitude of scientists recommended by [20] and [21]. In addition to presentation skills and arguments are also measured as critical thinking [7].

Researchers conduct an investigation of how the role of students in solving problems in groups. Students work in small groups and collaborate with group members to solve problems and then present the results in front of the class. They worked collaboratively with group members, while the tutor responsible for providing suitable instructional method and guidance to the respective groups. Interviews with students were conducted when presenting the results of group studies $[5 ; 22]$.

In critical thinking studies, several predictors might influence an individual's critical thinking. These include gender and age [23], and academic achievement [3]. However, based on the studies reviewed, generally no relationship between age and critical thinking, gender role produces inconclusive findings, while academic achievement shows relationship on students' critical thinking ability. 
The ability to think critically cognitively relates to information and experiences received then long term memory. Students construct thoughts based on observation and real experience. The information is then dissociated and accommodated into new knowledge. The cognitive strategy is an essential instrument in learning to understand the material content. Then cognitive and metacognitive strategies have to work altogether [22].

The ability to communicate research results orally is an assessment to measure critical thinking skills. A deep understanding of science concepts helps students in critically arguing skills. Students are more confident to convey new ideas based on an understanding of the concept of science. The skills of communicating in writing or presentation should be empowered to all students as reflecting on an understanding of the concept of science [21]. The increased ability critical thinking is an activity in the PjBL learning model. Students should be aware that in PjBL to understand the concept of science is not sufficiently cognitive only but there is cognitive alignment, skill and scientific attitude.

\section{CONCLUSION}

PjBL is applied effectively to empowercritical thinking skills in preservis teacher in Primary Education Program. Critical thinking skills are individualized with varying degrees of ability. PjBL engages students to be actively involved in analyzing, solving problems and drawing conclusions. This activity requires students to be independent. the findings of this paper can offer valuable implications and vital recommendations for university managers and prospective studies. The limitation of this study is short observation time so it does not cover all aspects of critical thinking. For the next stage of research it will take longer time and larger respondents.

\section{ACKNOWLEDGEMENT}

The authors would like to thank the Institute of Research and Community Services at Universitas Sebelas Maret for the financial support.

\section{REFERENCES}

[1] Collins, R. (2014). Skills for the 21st Century : teaching higher-order thinki, 12(14).

[2] Echols, J.M. 1992. An Indonesian-English Dictionary. Jakarta. Published by Gramedia Pustaka Utama

[3] Facione,. (1990). Critical thinking: A statement of expert consensus for purposes of educational assessment and instruction, The Delphi Report. 1-19, California: California Academic Press.

[4] Wan, Y., \& Wong, A. F. L. (2015). Effects of the constructivist learning environment on students ' critical thinking ability: Cognitive and motivational variables as mediators. International Journal of Educational Research, 70, 68-79. https://doi.org/10.1016/j.ijer.2015.02.006

[5] Masek, A., \& Yamin, S. (2012). The Impact of Instructional Methods on Critical Thinking: A Comparison of Problem-Based Learning and Conventional, 2012. https://doi.org/10.5402/2012/759241

[6] Yeoman, K. H., \& Zamorski, B. (2008). Investigating the impact on skill development of an undergraduate scientific research skills course. Bioscience Education, 11-5. Retrieved from www. bioscience.heacademy.ac.uk/journal/vol11/beej-11-5.aspx 
[7] Iwamoto, D. H. (2016). The Effect of Project-Based Learning on Student Performance: An Action Research Study. International Journal for the Scholarship of Technology Enhanced Learning, 1(1), 24-42.

[8] Fernate, A. (2009). Research-Based Academic Studies: Promotion of the Quality of Learning Outcomes in Higher Education.

[9] Park, B., Plass, J. L., \& Brünken, R. (2014). Cognitive and affective processes in multimedia learning. Learning and Instruction, 29, 125-127. https://doi.org/10.1016/j.learninstruc.2013.05.005.

10. Panasan, M., Nuangchalerm, P., \& Muang, A. (2010). Learning Outcomes of Project-Based and Inquiry-Based Learning Activities Department of Curriculum and Instruction , Faculty of Education , Mahasarakham University , Mahasarakham 44000 Thailand, Journal of Social Sciences,6(2), 252255.

11. Bell, S. (2010). Project-Based Learning for the 21st Century : Skills for, The Clearing House,83, 39-43. https://doi.org/10.1080/00098650903505415

12. Magnusson, S., Krajcik, J., \& Borko, H. (1999). 4 . Nature , Sources , and Development of Pedagogical Content Knowledge for Science Teaching. PCK and Science Education, 95-132.

13. Hsu, P., Dyke, M. Van, Chen, Y., \& Smith, T. J. (2016). A cross-cultural study of the effect of a learning vironment on middle school students ' science knowledge and argumentation skills, Journal of Computer Assisted Learning, 32. 51-76. https://doi.org/10.1111/jcal.12118

14. Talat, A., \& Chaudhry, H. F. (2014). The Effect of PBL and 21st Century Skills on Students ' Creativity and Competitiveness in Private Schools, The Lahore Journal of Business 2(Spring), 89-11

15. Ge.X., Lourdes. G., Planas, Nelson. 2010. A Cognitive Support System to Scaff old Students ' Problem-based Learning in a Web-based Learning Environment Literature Review. The Interdisciplinary Journal of Problem-based Learning 4 no. 1

16. Bensley, D. A., \& Spero, R. A. (2014). Improving critical thinking skills and metacognitive monitoring through direct infusion. Thinking Skills and Creativity, 12, 55-68. https://doi.org/10.1016/j.tsc.2014.02.001

17. Manoli, C., Pedaste, M., Mario, M., Siiman, L., De, T., Riesen, S. A. N. Van, ... Jong, T. De. (2015). Phases of inquiry-based learning: definitions and the inquiry cycle To cite this version: Educational Research Review, 14, 47-61. https://doi.org/10.1016/j.edurev.2015.02.003

18. Aloqaili, A. S. (2012). The relationship between reading comprehension and critical thinking: A theoretical study. Journal of King Saud University - Languages and Translation, 24(1), 35-41. https://doi.org/10.1016/j.jksult.2011.01.001

19. Ramasundaram, V., Grunwald, S., Mangeot, A., Comerford, N. B., \& Bliss, C. M. (2005). Development of an environmental virtual field laboratory. Computers and Education. 45, 21-34.

20. Field, D. J., Koppi, A. J., Jarrett, L. E., Abbott, L. K., Cattle, S. R., Grant, C. D., \& Weatherley, A. J. (2011). Soil science teaching principles. Geoderma, 167, 9-14.

21. Ak, O., \& Özkarde, R. (2007). The Effects of Problem-Based Active Learning in Science Education on Students 'Academic Achievement, Attitude and Concept,Eurasia Jounal of Mathematic, Science and Technology Education. 3(1), 71-81.

22. Ennis, R.H., Millman and Tomko, T. (2005). The Cornell Critical Thinking Tests, Level X and Z, (5th ed. revised). Pacific Grove, California: Midwest Publication.

23. Behzadi, M., Lotfi, F. H., \& Mahboudi, N. (2014). The Study of Teaching Effective Strategies on Student â€ $€^{\mathrm{TM}}$ s Math Achievements, 2014, 1-8. https://doi.org/10.5899/2014/metr-00040 